\title{
Peran Komunikasi Dalam Keluarga Kristen Berdasarkan Ulangan 6:7
}

\author{
Benyamin Telnoni, ${ }^{1} *$ Anggelina Cindy Debora Ladi ${ }^{2}$ \\ Mahasiswa Prodi Magister MPAK UKI Jakarta \\ Mahasiswa Prodi PAK FKIP UKI Jakarta \\ Benyamin93.Telnoni@gmail.com
}

\begin{abstract}
Through this article, the author attempts to describe the crucial role of communication in the family based on Deuteronomy 6: 7. Damage to family relationships: husband and wife, parentchild due to stagnant communication between family members. According to the Indonesian Family Home Counselor and Trainer (RKI) that 70\% of husband and wife problems are due to communication failures. Even the Head of Prosperous Family and Family Empowerment $(K S P K)$ in Media Indonesia revealed that poor communication between parents and children can result in juvenile delinquency. This means that communication has a very important role in the Christian family. Good or bad a family is determined by how to communicate with family members because effective communication can help prevent problems in the family. Good communication can help parents to prepare the best path for the child's future, including in directing their children to achieve their desired goals. Text analysis of Deuteronomy 6:7 shows that communication between families plays a central role in bringing harmonious and open family to one another. The purpose of this paper is to answer all the problems regarding the role of communication in the Christian family and in review from Deuteronomy 6: 7. The method used in this paper is the method of studying literature and library research.
\end{abstract}

Keywords: Communication, Christian family, Deuteronomy 6:7

\begin{abstract}
Abstrak
Melalui artikel ini, penulis berupaya untuk menguraikan krusialitas peran komunikasi dalam keluarga berdasarkan Ulangan 6:7. Rusaknya hubungan keluarga: suami-istri, orang tua-anak karena mandegnya komunikasi antar anggota keluarga. Menurut Konselor dan Trainer Rumah Keluarga Indonesia (RKI) bahwa 70\% persoalan suami istri Karena kegagalan komunikasi. Bahkan Kepala Bidang Keluarga Sejahtera dan Pemberdayaan Keluarga (KSPK) dalam Media Indonesia mengungkapkan buruknya komunikasi antara orang tua dan anak dapat mengakibatkan kenakalan remaja. Artinya bahwa komunikasi memiliki peran yang sangat penting dalam keluarga kristen. Baik atau buruknya sebuah keluarga sangat ditentukan dari cara berkomunikasi dengan anggota keluarganya karena komunikasi yang efektif bisa membantu mencegah masalah dalam keluarga. komunikasi yang baik bisa membantu orang tua untuk menyiapkan jalan terbaik masa depan anak, termasuk dalam mengarahkan anaknya untuk mencapai cita-citanya yang diharapkan. Analisis teks terhadap Ulangan 6:7 menunjukkan bahwa Komunikasi antar keluarga memainkan peran sentral dalam mewujukan keluarga harmonis dan terbuka satu sama lain. Tujuan dari penulisan ini adalah untuk menjawab segala persoalan mengenai peran komunikasi dalam keluarga kristen dan ditinjau dari ulangan 6:7. Metode yang digunakan dalam penulisan ini adalah metode kajian literatur dan riset pustaka.
\end{abstract}

Kata kunci: Komunikasi, keluarga Kristen, ulangan 6:7

\section{PENDAHULUAN}

Komunikasi yang tersumbat akan menghancurkan kehangatan dalam rumah tangga tangga. Banyak sekali masalah yang sering terjadi dalam kalangan masyarakat baik itu masalah keuangan, perceraian dan kekerasan dalam rumah tangga sehingga mengakibatkan keretakan dan kehancuran dalam keluarga disebabkan karena kurangnya komunikasi yang baik antar anggota keluarga, sehingga menimbulkan persoalan yang genting. Suara Surabaya (2007) dalam Julianto Simanjuntak mengatakan, "Di Indonesia, 
$30 \%$ perceraian terjadi karena salah satu pasangan meninggalkan tanggung jawabnya terhadap keluarga"” Peran dan tanggung jawab ada di dalam komunikasi. Dalam keluarga Kristen permasalahan juga sering terjadi, bahkan berujung perceraian karena kurangnya komunikasi yang terjalin antara suami dan istri. Masalah sepele yang seharusnya bisa diatasi tetapi berlanjut menjadi masalah yang besar karena komunikasi yang tidak dibangun dengan baik.

Komunikasi bukan hanya sebuah ilmu pengetahuan yang hanya dapat dipahami semata, tetapi memiliki seni dalam bergaul atau berinteraksi dengan orang lain. Supaya dapat berkomunikasi dengan efektif maka setiap orang dituntut bukan hanya memahami proses penyampaian pesan, tetapi juga mampu mengaplikasikan pengetahuannya secara kreatif dalam proses berkomunikasi ${ }^{2}$. Dalam ilmu komunikasi, kehidupan sebuah keluarga yang terdiri atas suami, istri dan anak tidak terlepas dari berbagai macam persoalan, baik itu bersumber dari suami, isteri ataupun dari anaknya sendiri, karena dalam sebuah institusi yang hidup dan berinteraksi dengan lingkungan sekitar, mereka akan selalu dipengaruhi dan mempengaruhi orang lain sehingga hal itu dapat berimplikasi pada keharmonisan serta keutuhan dalam keluarga itu sendiri.

Keluarga Kristen bermula dari pemahaman berdasarkan Alkitab bahwa Allah menciptakan keluarga (Kejadian 1:26-27). dalam hal ini manusia diciptakan seturut dengan gambar Allah (Imago Dei) ${ }^{3}$. Jika keluarga Kristen menyadari bahwa panggilannya adalah sebagai gambar Allah (Imago Dei), maka seharusnya relasi atau hubungan yang dibangun melalui komunikasi dalam keluarga harus melibatkan Allah. Dalam kehidupan keluarga Israel sangat jelas dalam Ulangan 6:7 dimana teks tersebut menekankan bahwa orangtua harus mengajarkannya berulang-ulang atau terus menerus dalam keadaan apapun, disini orangtua harus berperan penting untuk membangun komunikasi yang efektif dengan anggota keluarganya seperti komunikasi yang sudah dibangun oleh Allah dengan Adam dan Hawa di taman Eden. Dalam sebuah keluarga Kristen yang terdiri dari suami dan istri harus memiliki kemampuan untuk membangun komunikasi yang baik dan sehat. Oleh karen itu, dari latar belakang diatas maka tujuan dari penulisan artikel ini adalah untuk menjawab segala persolan yang terjadi dalam keluarga kristen dan memberikan sebuah pemahaman yang baru bahwa peran komunikasi dalam keluarga khususnya bagi keluarga kristen sangat penting untuk mengatasi segala masalah yang terjadi.

\section{HASIL DAN PEMBAHASAN}

\section{Ulangan 6:7}

Dalam kitab ulangan khususnya pada pasal 6 Musa menasihati umat israel untuk mengingat perbuatan-perbuatan Allah dalam perjalanan sejarah mereka, untuk mengajarkan semua perintah Allah untuk mengasihi dan melayani-Nya. Menurut Antone menjelaskan bahwa pendidikan sebelum pembuangan sebagian dijelaskan dalam ulangan pasal 6 yang menyiratkan pola kehidupan keluarga israel yang kuat dan memberikan latar belakang bagi pemeliharaan iman ${ }^{4}$.

\footnotetext{
1 Julianto Simanjuntak, Mendidik Anak Utuh, Menuai Keluarga Tangguh (Tangerang: Yayasan Pelikan, 2017). 24-25

2 Patrix Brando Rimporok, "Intensitas Komunikasi Dalam Keluarga Untuk Meminimalisir Kenakalan Remaja Di Desa Maumbi Kecamatan Kalawat Kabupaten Minahasa Utara," Journal "Acta Diurna" Iv, No. 1 (2015): 1-12, Https://Media.Neliti.Com/Media/Publications/89897-Id-Intensitas-Komunikasi-Dalam-Keluarga-Unt.Pdf.

3 Juliman Harefa, "Makna Allah Pencipta Manusia Dan Problematika Arti Kata 'Kita' Dalam Kejadian 1: 26-27" 3, No. 2 (2019): 107-117.

${ }^{4}$ Hope S. Antone, Pendidikan Kristiani Kontekstual (Jakarta: Bpk Gunung Mulia, 2010). 18
} 
Shema Israel merupakan tanggung jawab orang tua kepada anak-anaknya untuk mengajarkan firman Tuhan kepada keluarganya melalui pembiasaan, pemahaman serta pengahayatan akan firman Tuhan yang dilaksanakan dalam keluarga dibawah bimbingan orang tua. Menurut Sjamsuri gagasan atau konsep memiliki makna yang sangat penting untuk mengumpulkan dan diterapkan, yakni membangun persekutuan dalam keluarga kristen yang diperankan oleh orangtua ${ }^{5}$. Poin penting yang perlu diperhatikan dalam perintah pengajaran yang harus dilakukan secara berulang-ulang, hal ini dimaksud bahwa segala ketetapan dan peraturan yang dimaksud pada bagian ini yaitu diajarkan secera terus menenus supaya dipahami dengan baik.

Dalam teks ulangan 6:7 dikatakan "Haruslah engkau mengajarkannya berualngulang kepada anak-anakmu dan membicarakannya apabila engkau duduk di rumahmu, apabila engkau sedang dalam perjalanan, apabila engkau berbaring dan apabila engkau bangun". Dalam bahasa ibrani teks dari "berulang-ulang" diterjemahkan dari kata "washinatam" dari kata dasar "shinan" yang berarti mempertajam6. Artinya bahwa sebuah pesan yang disampaikan oleh pemberi pesan kepada penerima pesan harus dimengerti dengan baik sehingga perlu untuk diajarkan secara berulang-ulang supaya pesan yang diterima jelas.

Dalam terjemahan KJV kata "diligently" berarti tekun, sedangkan dalam LAI diterjemahkan "berualng-ulang" yang secara harafiahnya yaitu meruncing atau mempertajamkan. Pesan yang ditonjolkan pada bagian ini yaitu sebuah proses pengajaran yang dilaksanakan seiring dengan tanggung jawab yang benar-benar tertanam dan mengsankan". Jadi teks "berulang-ulang" ini hanyalah cara atau proses pelaksanaan menyampaikan pesan tetapi tujuan dibalik ini adalah inti dari pesan yang disampaikan dapat tertanam dan terus dingat. Sedangkan kata "membicarakan" sama artinya dengan mempercakapkan. Ungkapan ayat ulangan 6:7 menunjukan bahwa apa yang menjadi sisi perintah yang harus dilakukan. Penerapan ayat ini sangat tepat kepada keluarga kristen yaitu mereka harus menuruti semua perintah melalui percakapan atau mengkomunikasikannya baik berada di rumah waktu duduk, waktu tidur, waktu bangun, maupaun dalam perjalanan.

\section{Pengertian Komunikasi}

Kesalahpahaman dan perbedaan pendapat dapat memicu sebuah perang atau konflik jika tidak adanya sebuah komunikasi yang baik. Akibat dari komunikasi yang tidak baik juga menimbulkan banyak informasi dan persepsi yang salah. Seseorang akan berusaha menafsir sesuatu tanpa dasar yang tepat jika tidak adanya komunikasi yang benar. Meskipun di era perceptan digital yang semakin canggih, pemahaman mengenai komunikasi masih kurang dipahami oleh masyarakat.

Dalam pengertiannya, komunikasi dalam Kamus Besar Bahasa Indonesia yaitu pengiriman dan penerimaan pesan atau berita dua orang atau lebih, menurut Andhita

\footnotetext{
5 Leonardo A. Sjamsuri, Keluarga Bahagia Ditengah Perubahan Zaman (Jakarta: Nafiri Gabriel, 2016). 34

6 Nelson Hasibuan, "Shema Israel Dan Implementasinya Dalam Pendidikan Keluarga Kristen Di Gbi Sumber Sari Bandung"

7 lbid. 25
} (N.D.). 19 
Sari memberi arti dasar yaitu komunikasi berasal dari kata Latin yaitu "communicatus" yang artinya adalah berbagi atau milik bersama hal ini juga tidak menunjukan kepada diri sendiri melainkan ada oknum lain yang terlibat ${ }^{8}$. Pesan atau informasi yang disampaikan tidak bisa diabaikan begitu saja, harus ada timbal balik, ada tanggapan yang terjadi baik langsung maupun tidak langsung sehingga komunikasi itu tidak hanya dilakukan oleh satu pihak. Selanjutanya Evi Novianti juga mengatakan bahwa dalam penyampaian pesan, jika penerima pesan mengabaikan pesan tersebut maka komunikasi yang dibangun akan sia-sia ${ }^{9}$. Komunikasi akan sangat efektif jika memiliki tujuan dan juga terjadi secara aktif tidak pasif. Oleh sebab itu komunikasi penting untuk dipahami dengan baik khususnya di dalam kehidupan keluarga. Kelompok sosial yang menggunakan durasi pertemuan dan komunikasi secara intens terjadi di dalam keluarga.

Komunikasi dalam keluarga masuk ke dalam ranah komunikasi antar pribadi. Wiryanto menjelaskan bahwa, "Komunikasi antarpribadi (interpersonal communication) merupakan komunikasi yang berlangsung dalam situasi tatap muka antara dua orang atau lebih, baik secara terorganisasi maupun pada kerumunan orang"10. Peluang terciptanya komunikasi yang baik dalam keluarga berdasarkan pengertian mengenai komunikasi antarpribadi harusnya dapat berjalan dengan baik. Umpan balik yang diharapakan juga bisa cepat diterima karena keluarga adalah lingkaran kelompok yang kecil. Namun inilah yang menjadi kendala yaitu keluarga di era sekarang ini dipenuhi dengan urusan masing-masing. Hal ini di karenakan banyaknya perubahan yang terjadi baik secara lingkungan, dan juga budaya. Masing-masing anggota lebih mengutamakan urusan pribadi ketimbang peduli dengan keadaan anggota keluarga yang lain. Kemudahan oleh zaman membuat sesama anggota keluarga mengabaikan bahwa dalam komunikasi keluarga bukan hanya saling menyampaikan pesan namun juga ada peran tatap muka yang penting untuk lebih saling memahami dan mengerti satu sama lain.

Komunikasi antarpribadi atau interpersonal communication dapat menjadi jembatan bagi seseorang dalam berkomunikasi. Oleh sebab itu komunikasi antarpribadi dapat melibatkan seluruh individu dalam berkomunikasi. Keterlibatan dari setiap individu dalam berkomunikasi akan menghasilkan alur komunikasi yang aktif.

\section{Ciri-ciri komunikasi dalam keluarga}

Komunikasi dalam keluarga dapat diartikan sebagai kesiapan untuk membicarakan dengan terbuka dalam segala hal baik menyenangkan dan tidak menyenangkan. Adapun beberapa ciri-ciri komunikasi dalam keluarga menurut sebagai berikut: ${ }^{11}$

1. Keterbukaan: Keterbukaan dalam komunikasi ini adalah sejauh mana individu memiliki keterbukaan dalam berinteraksi dengan orang lain. Keterbukaan yang terjadi dalam komunikasi tersebut memberikan tanggapan yang jelas terhadap pikiran dan perasaan yang diungkapkan.

\footnotetext{
${ }^{8}$ A. Andhita Sari, Komunikasi Antar Pribadi (Yogyakarta: Deepublish, 2017). 1-2

9 Evi Novianti, Teori Komunikasi Umum Dan Aplikasinya (Yogyakarta: Andi, 2019). 2-3

10 Wiryanto, Pengantar Ilmu Komunikasi (Jakarta: Grasindo, 2004). 32

11 Tutu April Ariani, Komunikasi Keperawatan (Malang: Universitas Muhammadiyah, 2018). 86
} 
2. Empati: Ciri komunikasi empati adalah dimana perasaan individu yang merasakan sama seperti yang dirasakan orang lain, tanpa harus secara nyata terlibat dalam perasaan atau respon dari orang tersebut.

3. Kesamaan: Kesamaan disini adalah bagaimana orang yang menyampaikan pesan mempunyai kesamaan dengan orang lain dalam hal berkomunikasi dan mendengarkan.

4. Perasaan Positif: Ciri ini adalah dimana individu harus mempunyai perasaan positif terhadap apa yang dikatakan oleh orang lain terhadap dirinya.

Dari keempat ciri-ciri ini maka komunikasi dalam keluarga kristen harus menerapkannya dalam keluarganya, agar hubungan dalam keluarga menjadi efektif.

\section{Pengertian Keluarga Kristen Dan Nilai-Nilainya}

Pendidikan Agama Kristen dengan berbagi praksis dapat diuraikan sebagai persekutuan orang Kristen dan berbagi dalam dialog reflekif. Groome mengatakan bahwa, "Hidup orang Kristen adalah hidup yang berbagi". Hidup yang berbagi artinya hidup yang tidak berpusat untuk diri sendiri melainkan kasih sebagai dasar untuk melihat kepada orang lain, dan di dalam keluarga hal itu dapat tercipta. Keluarga Kristen diawali dari kelurga Adam dan Hawa, diamana Allah memberikan perintah kepada mereka untuk membentuk sebuah keluarga yaitu untuk memperbanyak populasi serta bagaimana mereka bertanggung jawab dengan lingkungan yang Tuhan berikan bagi mereka untuk memeliharanya ${ }^{12}$.

Keluarga kristen bertumbuh dan dibangun berbeda dari keluarga yang lain atau keluarga pada umumnya. Dasar dari keluarga kristen adalah Yesus, di mana Yesus yang membangun dan menumbuhkan baik kasih sayang dan pengertian ke dalam keluarga tersebut. Yesus sebagai dasar inilah yang membedakan keluarga Kristen dan keluarga pada umumnya, artinya bahwa Yesus ikut terlibat dalam pembentukan keluarga tersebut. Sehingga seharusnya keluarga Kristen memiliki kehidupan yang penuh damai sejahtera.

Dalam keluarga Kristen tentu nilai-nilai yang berlaku didalamnya selalu bersumber dari firman Allah ${ }^{13}$. Nilai-nilai kristiani itu akan menjadi benih dan akan mengalami proses, proses tersebut akan menjadi suatu identitas dalam keluarga kristen. Sedangkan menurut Darmawijaya nilai-nilai kristen tumbuh menjadi iman, oleh sebab itu nilai-nilai kristiani bukanlah sebuah kebiasaan melainkan irama hidup ${ }^{14}$. Keluarga Kristen tidak lepas dari nilai-nilai kristiani contohnya seperti mengasihi, berbuat baik, ramah, sabar, saling menghormati, menolong dan menghargai. Nilai-nilai ini melekat bagi keluarga Kristen dan berpengaruh terhadap pertumbuhan anggota keluarga yang diwariskan dari generasi ke generasi.

Kehidupan keluarga Kristen setiap harinya adalah hidup yang berhubungan dengan Allah, membangun mezbah setiap hari dan selalu mengucap syukur. Oleh sebab itu pengalaman hidup bersama Allah yang menjadi suatu kesaksian bagaimana Yesus hadir ditengah-tengah keluarga tersebut itulah yang menjadi warisan iman untuk generasi selanjutnya. Kasih yang terjalin diantara suami dan istri adalah gambaran kasih

12 Thomas H Groome, Christian Religious Education: Sharing Our Story And Vision (Jakarta: Bpk. Gunung Mulia, 2010). 269

13 I.H Enklaar Dan E.G Homrighausen, Pendidikan Agama Kristen (Jakarta: Bpk Gunung Mulia, 2008). 58

${ }^{14}$ Darmawijaya, Mengarungi Hidup Berkeluarga (Yogyakarta: Kanisius, 1994). 9-10 
Allah kepada kehidupan keluarga Kristen sebagai Kasih Allah kepada umat-Nya. Oleh karena itu, keluarga Kristen perlu menjadi contoh atau teladan bagi orang lain, bahwa Yesus ada didalam keluarga mereka.

\section{Peran Komunikasi terhadap Keluarga kristen}

Membangun keluarga Kristen tentu bukan saja peran penuh dari seorang suami atau seorang ayah. Sekalipun suami adalah kepala keluarga namun tugas dan tanggung jawab membangun keluarga yang menghidupi nilai-nilai kristiani adalah kewajiban seluruh anggota keluarga. Allah membangungkan Hawa dari tulang rusuk Adam gunanya adalah untuk menjadi penolong. Begitu juga dengan anak-anak, bukan hanya tugas orang tua melahirkan anak melainkan membangun pengertian untuk anak-anak.

Kesatuan hati dan pikiran hanya dapat dicapai jika semua anggota keluarga memiliki pengertian yang sama. Maka disinilah peran komunikasi dalam keluarga. Komunikasi yang digunakan dalam keluarga adalah komunikasi antarpribadi dimana menbutuhkan lingkup kecil dengan tatap muka. Gunanya adalah untuk membentuk komunikasi yang lebih intim, lebih mendalam, pembahasan dalam komunikasi antarpribadi juga bisa pembahasan secara khusus. Setiap orang ingin dimengerti dan dipahami, tentunya senang jika pendapat kita diterima. Allah menciptakan Adam dan Hawa dengan dua pemikiran, karakter, dan sifat yang berbeda. Suami dan istri sekalipun sudah menikah, bersatu secara daging belum tentu pemikiran, perasaan, dan kehendak yang sejalan belum lagi jika ada anak-anak. Julianto Simanjuntak mengatakan, "Komunikasi merupakan inti kehidupan keluarga"15 Komunikasi menjadi hal yang penting dan tidak dapat disepelakan dalam keluarga. Melalui komunikasi setiap anggota keluarga dapat menyampaikan tujuan dan maksud pikiran serta perasaan.

Melalui komunikasi yang efektif, akan terhindar dari perasaan yang dipendam. Perasaan yang dipendam dan tidak menemukan jalur untuk ia keluar maka akan menyakiti diri sendiri dan bisa menciptakan permasalahan yang berulang-ulang. Dalam membangun iman serta nilai-nilai kristiani di dalam keluarga, jika tidak didasari dengan komunikasi yang baik maka hal itu hanyalah seperti suatu peraturan keluarga yang bisa untuk dilanggar. Komunikasi memberi pengertian terhadap nilai-nilai tersebut.

\section{KESIMPULAN}

Peran komunikasi dalam keluarga kristen sangat penting, karena melalui komunikasi kehidupan keluarga akan terlihat harmonis karena memiliki keterbukaan antara anggota keluarganya. keluarga yang bahagia adalah keluarga yang mempunyai jalinan komunikasi yang efektif di dalamnya. Komunikasi dikatakan efektif apabila didalamnya terjadi proses pendewasan, pematangan, pemulihan bagi setiap pribadi yang terlibat di dalam proses komunikasi tersebut baik itu suami, istri dan anak akan menghasilkan persatuan walaupun di tengah perbedaan pendapat, melahirkan rasa kebersaman yang kuat, saling memahami dan mengerti serta memperlihatkan sikap hormat, kasih dan kepedulian kepada orang lain, dan setiap pribadi yang terlibat dalam

15 Simanjuntak, Mendidik Anak Utuh, Menuai Keluarga Tangguh. 98 
proses itu dapat mengungkapkan pendapat dan perasaannya tanpa merasa tertekan oleh pihak yang lain.

\section{KEPUSTAKAAN}

Antone, Hope S. Pendidikan Kristiani Kontekstual. Jakarta: BPK Gunung Mulia, 2010.

Ariani, Tutu April. Komunikasi Keperawatan. Malang: Universitas Muhammadiyah, 2018.

Darmawijaya. Mengarungi hidup berkeluarga. Yogyakarta: Kanisius, 1994.

Groome, Thomas H. Christian Religious Education: Sharing Our Story and Vision. Jakarta: BPK. Gunung Mulia, 2010.

Harefa, Juliman. "Makna Allah Pencipta Manusia dan Problematika Arti Kata 'Kita' dalam Kejadian 1 : 26-27” 3, no. 2 (2019): 107-117.

Hasibuan, Nelson. "Shema Israel Dan Implementasinya Dalam Pendidikan Keluarga Kristen Di Gbi Sumber Sari Bandung” (n.d.).

Homrighausen, I.H Enklaar dan E.G. Pendidikan Agama Kristen. Jakarta: BPK Gunung Mulia, 2008.

Novianti, Evi. Teori komunikasi umum dan aplikasinya. Yogyakarta: Andi, 2019.

Rimporok, Patrix Brando. "Intensitas Komunikasi Dalam Keluarga Untuk Meminimalisir Kenakalan Remaja Di Desa Maumbi Kecamatan Kalawat Kabupaten Minahasa Utara.” Journal “Acta Diurna” IV, no. 1 (2015): 1-12. https://media.neliti.com/media/publications/89897-ID-intensitas-komunikasi-dalamkeluarga-unt.pdf.

Sari, A. Andhita. Komunikasi antar pribadi. Yogyakarta: Deepublish, 2017.

Simanjuntak, Julianto. Mendidik Anak Utuh, Menuai Keluarga Tangguh. Tangerang: Yayasan Pelikan, 2017.

Sjamsuri, Leonardo A. Keluarga bahagia ditengah perubahan zaman. Jakarta: Nafiri Gabriel, 2016.

Wiryanto. Pengantar ilmu komunikasi. Jakarta: Grasindo, 2004. 